Vol.1 No.1 Januari 2018

ISSN 2614-2775

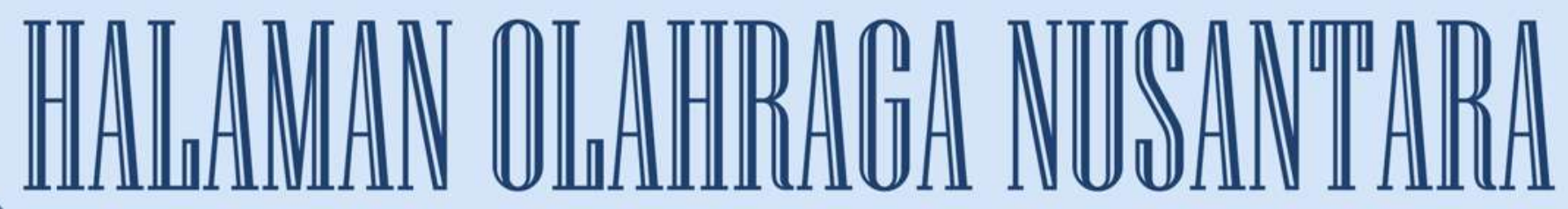

Curnal \&lmu Q Xeolahragaan

Diterbitkan Oleh:

Program Studi Pendidikan Olahraga

Pakultas Keguruan dan Ilmu Pendidikan

Universitas PGRI Palembang

\begin{tabular}{|c|c|c|c|c|c|}
\hline Jurnal & Volume & Nomor & Halaman & Palembang & ISSN \\
\hline IItaman Oahraya Vissantara & 1 & 1 & $1 \cdot 132$ & 2018 & 2014.27175 \\
\hline
\end{tabular}


Artikel Ilmiah

Perbedaan Variasi Latihan Juggling dan Rasio Koordinasi Mata-Kaki terhadap Hasil Kontrol Bola dari Tendangan Jarak Jauh Sepak Bola Hengki Kumbara

Hubungan Antara Kekuatan Otot Tungkai dan Kekuatan Otot Lengan terhadap Hasil Kecepatan Renang 50 Meter Gaya Bebas pada Atlet Putri Club Bangka Swimming

Farizal Imansyah

Motivasi Mahasiswa PGSD dalam Olahraga Rekreasi di Water Fun Kota Palembang

M. TaheriAkikbar

Pengaruh Metode Sirkuit terhadap Kemampuan Teknik Dasar Sepakbola pada Kegiatan Ekstrakurikuler Siswa SMAN 5 Kabupaten Tebo Alek Oktadinata

Kontribusi. Daya Ledak Otot Thung:kai dan Kelentukan dengan [1asil] Lompat Tinggi Gaya Flop Mahasiswa Program Studi Pendidikan Olahraga Universitas PG:RIPalembang IIham Arvan Junaidi

Kemampuan Meng.gining Bola (IStudi Korelasional Kecepatan ( $\left.x_{1}\right)$ dan Kelineahan $\left(x_{2}\right)$ dengan Kemampuan Dribel pada Permainan Sepabola Siswa Sekolah Menengah Pertama) Putwi Cicilla Kristina

Revitalisasi Masyarakat ¿iban/Perkotaan Melalui Olahraga Petanque Arcdo okilanda

Peranan Mata Pelajaran Pendidikan Jasmani dalam Meningkatkan Kesadaran Kesehatan \$iswa đi Lingkungan \$ekolah Dasar

Negeri nur Tegalkalong Kabupaten sumedang

№ Siti nurfaeni Sofa dan Anggi Setia Lengkana

Peran Motor Educability di dalam Meningkatan Keterampilan Olahraga pada Pembelajaran Penjas

gieru Syarili Lesmana

MơtivasiAnggota Pusat Kebugaran dalam Mengikuti Latihan Fitness padaKota Sekaycu Sugar Wanto

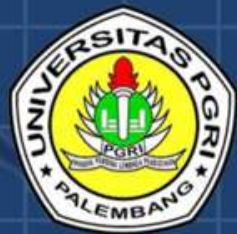

Program Studi Pendidikan Olahraga Fakultas Keguruan dan Ilmu Pendidikan Universitas PGRI Palembang 
ISSN 2614-2775

\section{HALAMAN OLAHRAGA NUSANTARA}

Jurnal Ilmu Keolahragaan

Volume 1, Nomor 1, Januari 2018

Pelindung/Penasehat

Dr. H. Bukman Lian, M. M., M. Si.

Penanggung Jawab

Dr. Dessy Wardiah, M. Pd.

Ketua Dewan Redaksi

Drs. M. Nirwan, M. Pd.

\section{Wakil Ketua Dewan Redaksi}

Ilham Arvan Junaidi, M. Pd.

\section{Sekretaris}

Nasrullah, M. Pd.

Penyunting Pelaksana

Rafel Orlando, M. Pd

Ardo Okilanda, M. Pd

\section{Penyunting Ahli/ Mitra Bestari}

Prof. Dr. A. Sofyan Hanif, M. Pd (Universitas Negeri Jakarta)

Dr. Ronni Yenes, M. Pd (Universitas Negeri Padang)

Dr. Putri Cicilia Kristina, M. Pd (Universitas PGRI Palembang)

\section{Tata Usaha}

M. Taheri Akbar, M. Pd

\section{Setting:}

Dede Dwiansyah Putra, M. Pd

Alamat Redaksi:

Prodi Pendidkan Olahraga Fakultas Keguruan Ilmu dan Pendidikan Universitas PGRI Palembang

Jl. Jendral A. Yani Lorong Gotong Royong 9/10 Ulu Palembang Telp. 0711-510043, Fax. 0711-514782

e-mail jurnal: rafelorlando333@gmail.com

e-mail : ardo.oku@ univpgri-palembang.ac.id

website: univpgri-palembang.ac.id 


\section{DAFTAR ISI}

Perbedaan Variasi Latihan Juggling dan Rasio Koordinasi Mata-Kaki terhadap Hasil Kontrol Bola dari Tendangan Jarak Jauh Sepak Bola

Hubungan Antara Kekuatan Otot Tungkai dan Kekuatan Otot Lengan terhadap Hasil Kecepatan Renang 50 Meter Gaya Bebas pada Atlet Putri Club Bangka Swimming

- Farizal Imansyah

Motivasi Mahasiswa PGSD dalam Olahraga Rekreasi di Water Fun Kota Palembang

- $\quad$ M. Taheri Akhbar

Pengaruh Metode Sirkuit terhadap Kemampuan Teknik Dasar Sepakbola pada Kegiatan Ekstrakurikuler Siswa SMAN 5 Kabupaten Tebo

- Alek Oktadinata

Kontribusi Daya Ledak Otot Tungkai dan Kelentukan dengan Hasil Lompat Tinggi Gaya Flop Mahasiswa Program Studi Pendidikan Olahraga Universitas PGRI Palembang

- Ilham Arvan Junaidi

Kemampuan Menggiring Bola (Studi Korelasional Kecepatan $\left(\mathrm{x}_{1}\right)$ dan Kelincahan $\left(\mathrm{x}_{2}\right)$ dengan Kemampuan Dribel pada Permainan Sepabola Siswa Sekolah Menengah Pertama)

- Putri Cicilia Kristina

Revitalisasi Masyarakat Urban/Perkotaan Melalui Olahraga Petanque

- $\quad$ Ardo okilanda

Peranan Mata Pelajaran Pendidikan Jasmani dalam Meningkatkan

Kesadaran Kesehatan Siswa di Lingkungan Sekolah Dasar

Negeri III Tegalkalong Kabupaten Sumedang

- $\quad$ N. Siti nur'aeni Sofa dan Anggi Setia Lengkana

Peran Motor Educability di dalam Meningkatan Keterampilan

Olahraga pada Pembelajaran Penjas

- Heru Syarli Lesmana 
Motivasi Anggota Pusat Kebugaran dalam Mengikuti Latihan Fitness pada Kota Sekayu

Sugar Wanto 


\title{
KEMAMPUAN MENGGIRING BOLA (STUDI KORELASIONAL KECEPATAN DAN KELINCAHAN DENGAN KEMAMPUAN DRIBEL PADA PERMAINAN SEPAKBOLA SISWA SEKOLAH MENENGAH PERTAMA)
}

\author{
Oleh: Putri Cicilia Kristina \\ (Dosen Universitas PGRI Palembang)
}

\begin{abstract}
Abstrak
Penelitian ini bertujuan untuk mengetahui apakah terdapat hubungan kecepatan $\left(X_{1}\right)$ dan kelincahan $\left(X_{2}\right)$ dengan keterampilan dribble bola $(Y)$ pada permainan sepakbola Siswa Putra. Metode yang digunakan pada penelitian ini adalah metode Korelasional (hubungan). Populasi dan sampel adalah siswa putra sebanyak 30 siswa, seluruh populasi mejadi sampel penelitian. Teknik pengumpulan data dilakukan tes pada setiap variabel, dilakukan uji statistik dengan rumus korelasi, melalui analisis korelasi regresi sederhana dan analisis regresi korelasi berganda. Hasil pengolahan dan analisis data hubungan kecepatan dengan kemampuan dribble bola diperoleh hasil sebesar $r=0,67$ berarti kontribusi kecepatan sebesar 67\%. Hubungan kelincahan dengan hasil dribble bola sebesar $r=$ 0,63 kontribusi kelincahan sebesar 63\%, Sedangkan hubungan kecepatan dan kelincahan secara bersama-sama dengan hasil dribble bola sebesar $R=0,67$ berarti kontribusi kedu variabel tersebut sebesar 67\%. Berdasarkan hasil analisis dan pembahasan, maka disimpulkan kedua variabel $X_{1}$ dan $X_{2}$ secara bersama-sama memiliki hubungan yang cukup segnifikan dengan sumbangan $67 \%$, artinya diatas $50 \%$, walaupu tidak maksimal hubungan kedua variabel, berarti masih ada variabel lain yang mempengaruhi.
\end{abstract}

Kata Kunci : Kecepatan, Kelincahan, Dribble, Sepak bola

\section{BILITY OF BALLING \\ (CORRELATIONAL STUDY OF SPEED AND AGILITY WITH DRIBEL ABILITIES FOOTBALL GAME IN THE SECONDARY SCHOOL STUDENT)}

\begin{abstract}
This study aims to determine whether there is a correlation of speed (X1) and agility (X2) with dribblel skills (Y) on the game male football student. The method used in this research is correlation method. Population and sample are male students as many as 30 students, the entire population becomes the research sample. Data collection techniques were tested on each variable, tested statistically with correlation formula, through simple regression correlation analysis and multiple correlation regression analysis. Results of processing and data analysis of speed correlation with dribble ball capability obtained results of $r=0.67$ means the
\end{abstract}


contribution speed of $67 \%$. Correlation agility with dribble ball result of $r=0.63$ agility contribution of $63 \%$, While the correlation speed and agility together with the dribble ball of $R=0.67$ means the contribution both of variable is 67\%. Based on the results of the analysis and discussion, it is concluded that both variables $X 1$ and $X 2$ together have a significant correlation with $67 \%$ contribution, meaning that above $50 \%$, although not maximal correlation between the two variables, it means there are other variables that influence.

Keywords: Speed, Agility, Dribble, Football

\section{A. PENDAHULUAN}

Suroto (2004: 6) berpendapat bahwa sepakbola adalah permainan yang sangat popular diseluruh masyarakat baik di Indonesia maupun diseluruh dunia. Sepakbola adalah jenis permainan beregu dengan jumlah 11 orang untuk masingmasing regu yang terdiri dari pemain depan, tengah dan belakang. Begitu juga Luxbacher (2012: 2) menyatakan bahwa sepakbola dimainkan oleh 2 tim yang masing-masing tim mempertahankan gawangnya dan berusaha menjebol gawang lawan dengan jumlah masing-masing tim 11 orang pemain. Sepak bola merupakan salah satu cabang olahraga yang paling sukses ditinjau dari segi pemasalahan, diseluruh pelosok tanah air dari semua lapisan masyarakat gemar baik sebagai penonton, maupun memainkannya, tetapi prestasi yang diraih masih sangat memprihatinkan pada saat ini. Tentunya ini ada yang salah dalam penglolaannya, baik dalam pembinaan maupun sistim organisasinya. Karena orang-orang yang berkecimpung didalam kurang memiliki kompetensi. Seperti pengurus banyak dikuasai oleh orang-orang yang tidak memiliki latar belakang sepak bola, pelatih juga banyak diisi oleh orang-orang tidak memahami Ilmu Pengetahuan dan Teknologi di bidangnya. Olahraga diabad moderen tidak hanya berbekal pengalaman tetapi harus melibatkan Ilmu Pengetahuan dan Teknologi.

Untuk menciptakan seorang pemain bola, salah satunya harus memiliki kondisi fisik yang prima. Untuk mengetahui kondisi fisik dilakukan melalui tes yang berkaitan dengan skill fitnes (Sukirno \& Waluyo, 2016: 57). Tes tersebut untuk mengetahui komponen-komponen fisik yang diperlukan. Diantaranya 
kecepatan, kelentukan, keseimbanan, kelincahan, kekuatan, daya tahan dan keseimbangan. Seorang yang memiliki komponen fisik yang baik, maka secara langsung akan mampu melakukan teknik-teknik yang baik pula. Seperti halnya teknik menggiring bola atau dribel. Dribble merupakan kemampuan seseorang dalam menggiring bola dengan menendang bola kecil-kecil, tetapi tetap dalam penguasaannya.

Adapun hambatan-hambatan yang sering terjadi pada saat menggiring bola adalah keluesan, orang yang tidak memiliki keluesan, maka akan mengurangi keterampilan dalam menggiring bola atau dribble sepak bola. Dalam teori tersebut terdapat solusi yang harus dimiliki dalam penelitian agar siswa dapat melakukan dribble bola dengan baik dan benar, maka perlu meningkatakan kemampuan fisiknya terutama yang berkaitan dengan meningkatkan kecepatan dan kelincahan. Kecepatan adalah kemampuan bergerak memindahkan tubuh secepat mungkin (Sukirno, 2012: 9).

Menurut Widiastuti (2011: 110), daya ledak merupakan faktor utama dalam pelaksanaan segala macam keterampilan gerak berbagai cabang olahraga, karena daya ledak adalah kemampuan untuk mengerahkan kekuatan maksimal dalam waktu yang sangat cepat. Keberhasilan dalam sepakbola ialah penguasaan dan kemampuan menerapkan teknik dasar secara konsisten dan efektif (Jones, 1998: 7). Salah satu keterampilan dalam permainan sepak bola adalah menggiring bola, tetapi dalam permainan sepak bola modern saat ini hal itu sudah jarang terjadi, karena sifat permainan sepak bola masa kini membuat keterampilan seperti itu sulit dilaksanakan. Padahal keterampilan menggiring bola merupakan sisi penting dalam permainan sepak bola. Pelaksanaan sepak bola melalui pelatihan kondisi fisik. Menurut I Gusti Ngurah Nala (2011: 84), kesegaran jasmani merupakan komponen yang sangat penting dalam mendukung kinerja fisik. Termasuk pada pemain bola. Berdasarkan pembahasan-pembahsan di atas maka peneliti memiliki suatu prediksi bahwa komponen kelincahan dan kecepatan memiliki kontribusi dalam keterampilan menggiring bola. Prediksi- 
prediksi tersebut didasarkan pada karakter permainan sepak bola yang mengedepankan komponen kelincahan dan kecepatan.

Berdasarkan penjelasan di atas, maka peneliti ingin membuktikan bahwa kecepatan dan kelincahan akan memberikan sumbangan untuk meningkatkan keterampilan dalam menggiring bola pada permainan sepak bola. Hubungan drible. adalah ikatan atau kontak antara dua individu atau lebih, atau antara kelompok-kelompok, dan sebagainya, yang sifatnya asosiatif atau disosiatif langsung atau tidak langsung. Hubungan merupakan keadaan yang selalu terjadi didalam kehidupan manusia. Hubungan merupakan interaksi antara suatu hal atau individu dengan individu atau hal lainnya. Jadi proses terjadinya hubungan apabila terdapat dua atau lebih individu atau hal yang berbeda namun melakukan interaksi atau kontak antara satu sama lain sehingga terjadi interaksi atau timbal balik antara keduannya.

Korelasi adalah suatu alat statistik, yang dapat digunakan untuk membandingkan hasil pengukuran dua variable yang berbeda agar dapat menentukan tingkat hubungan antara variabel-variabel ini (Arikunto, 2010: 313). Berdasarkan uraian di atas bahwa hubungan dalam penelitian ini adalah keterkaitan antara dua atau lebih variabel, yang melakukan interaksi satu sama lain sehingga terjadi interaksi. Dalam penelitian ini hubungan (korelasi) yang dimaksud adalah hubungan antara kecepatan dan kelincahan dengan hasil keterampilan dribble bola pada permaianan sepak bola.

\section{B. METODE PENELITIAN}

Berdasarkan rumusan masalah dan tujuan penelitian, maka jenis penelitian ini adalah penelitian korelasional, bertujuan untuk mendeskripsikan kekuatan hubungan antara dua atau lebih peristiwa atau sifat. Atau menggambarkan tentang hubungan antara variabel bebas yaitu kecepatan $\left(\mathrm{X}_{1}\right)$ dan kelincahan $\left(\mathrm{X}_{2}\right)$ dengan variable terikat yaitu dribble bola pada permainan sepak bola di Sekolah Menengah Pertama. Populasi adalah keseluruhan subjek 
penelitian. Apabila seseorang ingin meneliti semua elemen yang ada dalam wilayah penelitian, maka penelitiannya merupakan penelitian populasi. Studi atau penelitiannya juga disebut studi populasi atau studi sensus (Arikunto. 2010: 173) .Populasi yang menjadi obyek penelitian sebanyak 100 siswa.

Sampel adalah bagian dari jumlah dan karakteristik yang di miliki oleh populasi tersebut. Apabila dalam suatu penelitian populasi besar maka tidak mungkin peneliti meneliti semua yang ada dalam populasi, dengan alasan keterbatasan dana, waktu, dan tenaga maka peneliti dapat menggunakan sampel yang di ambil dari populasi tersebut. Oleh karena itu, sampel yang diambil seluruh siswa putra dari populasi tersebut. Dalam pengambilan sampel apabila subjeknya kurang dari 100, lebih baik di ambil semua sehingga penelitiannya merupakan penelitian populasi. Selanjutnya, apabila subjeknya lebih dari 100 dapat diambil antara 10-15\% atau 20-25\% (Sugiyono, 2008: 112). sampel penelitian sebanyak 30 siswa. Adapun teknik sampel menggunakan random sampling sederhana.

\section{Konstelasi penelitian}

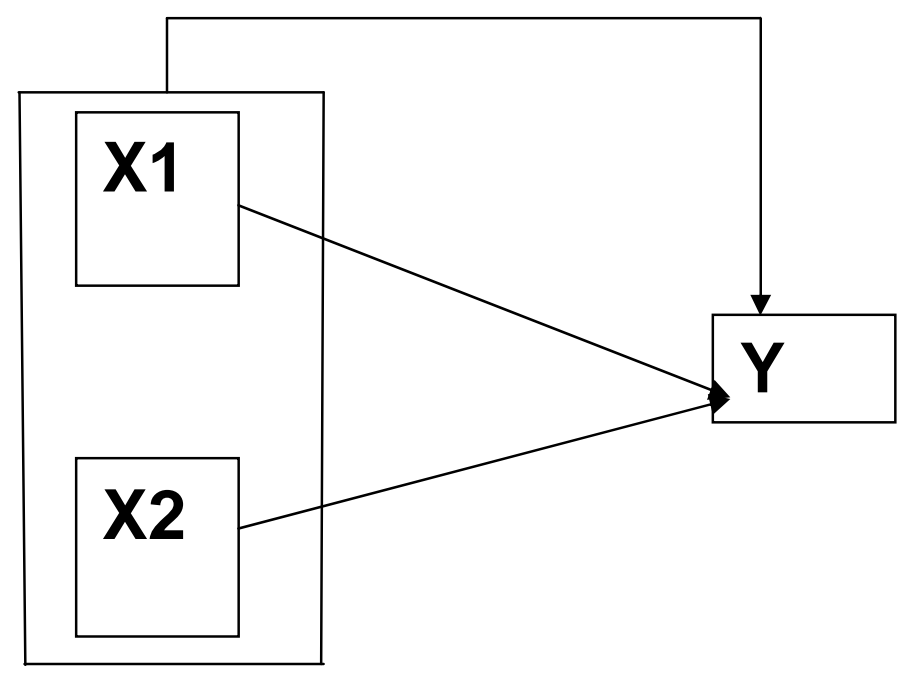


Keterangan:

$\mathrm{X}_{1}=$ Kecepatan

$\mathrm{X}_{2}=$ Kelincahan

$\mathrm{Y}=$ dribble bola

Untuk menguji hipotesis antara $\left(X_{1}, Y\right)$ dan $\left(X_{2}, Y\right)$ merupakan hubungan atau korelasi linier sederhana, maka dapat dianalisis menggunakan koefisien korelasi regresi linier sederhana sebagai berikut (Sugiyono, 2011: 144).

$$
r=\frac{n \sum_{i=1}^{n} x_{1 i} y_{i}-\left(\sum_{i=1}^{n} x_{1 i}\right)\left(\sum_{i=1}^{n} y_{i}\right)}{\sqrt{\left[n \sum_{i=1}^{n} x_{1 i}{ }^{2}-\left(\sum_{i=1}^{n} x_{1 i}\right)^{2}\right]\left[n \sum_{i=1}^{n} y_{i}{ }^{2}-\left(\sum_{i=1}^{n} y_{i}\right)^{2}\right]}}
$$

Nilai "r" yang dihasilkan hanya berlaku pada seluruh sampel, untuk menguji apakah harga " $r$ " tersebut berlaku untuk seluruh populasi, maka dilakukan uji signifikansi. Uji signifikansi korelasi secara praktis dilakukan dengan membandingkan harga $\mathbf{r}_{\text {hitung }}$ dengan harga $\mathbf{r}_{\text {tabel }}$. ketentuannya bila harga $\mathbf{r}_{\text {hitung }}$ lebih besar dari $\mathbf{r}_{\text {tabel, }}$ maka $\mathbf{r}_{\text {hitung }}$ signifikan, artinya $\mathbf{r}_{\text {hitung }}$ dapat diberlakukan pada populasi dimana sampel diambil (Sugiyono, 2011: 264).

\section{Uji Regresi Linier Berganda}

Untuk menguji hipotesis antara $\left(X_{1}, X_{2}\right.$ dan $\left.Y\right)$ dapat dianalisis menggunakan Koefisien korelasi regresi linier berganda sebagai berikut (Sugiyono, 2011: 157).

$$
R^{2}=\sqrt{\frac{a_{1} \sum_{i=1}^{n} y_{i} x_{1 i}+a_{2} \sum_{i=1}^{n} y_{i} x_{2 i}}{\sum_{i-1}^{n} y_{i}{ }^{2}}}
$$




\section{HASIL DAN PEMBAHASAN}

\section{Data Hasil Kecepatan $\left(\mathrm{X}_{1}\right)$}

Penelitian ini melakukan pengukuran kecepatan untuk mengetahui hubungan kelincahan dengan hasil dribble bola kaki. Hasil data yang dikumpulkan mengenai kecepatan diperoleh skor tertinggi yang dicapai sebesar 6,94, sedangkan skor terendah adalah sebesar 4,00, setelah data di analisis diperoleh harga rata-rata sebesar 5,29, modus 5,25, dan simpangan baku 0,66.

2. Data Hasil Kelincahan $\left(\mathrm{X}_{2}\right)$

Penelitian ini menggunakan tes kelincahan untuk mengetahui hubungan kelincahan dengan hasil dribble bola kaki. Hasil data yang dikumpulkan mengenai kelincahan diperoleh skor tertinggi yang dicapai 6,79, sedangkan skor terendah adalah sebesar 4,78. berdasarkan data tersebut di analisis diperoleh harga rata-rata sebesar 5,71, modus 5,60, dan simpangan baku sebesar 0,47.

\section{Data Hasil Dribble Bola Kaki (Y)}

Penelitian ini menggunakan tes dribble bola kaki. Hasil data yang dikumpulkan mengenai dribble bola kaki diperoleh skor tercepat yang dicapai 7,65 detik, sedangkan skor paling lambat adalah 16,52 detik. Berdasarkan data tersebut di analisis diperoleh harga rata-rata sebesar 10,51 detik, modus 9,42 detik, dan simpangan baku sebesar 2,19 detik.

Hubungan kecepatan dengan dribble bola kaki dapat diinterpretasikan dengan mengukur koefisien korelasi " $r$ ". Besar koefisien korelasi antara kecepatan dengan dribble bola kaki adalah sebesar $\boldsymbol{r}_{\text {hitung }}$ sebesar 0,67, termasuk dalam kategori tingkat hubungan yang cukup tinggi. Berarti ada hubungan kecepatan dengan dribble bola kaki pada siswa putra Sekolah Menengah Pertama dengan kotribusi sebesr $67 \%$ sumbangan kecepatan terhadap hasil drible pada permainan sepak bola, meskipun kontribusinya tidak maksimal.

Menurut Arikunto (2010: 365), apabila harga $\mathrm{r}$ bernilai positif menyatakan adanya hubungan linier sempurna langsung antara $\mathrm{X}$ dengan $\mathrm{Y}$. Ini berarti bahwa titik-titik yang ditentukan oleh $(\mathrm{X}, \mathrm{Y})$ seluruhnya terletak pada 
garis regresi linier dan harga $\mathrm{X}$ yang besar menyebabkan atau berpasangan dengan $\mathrm{Y}$ yang kecil sedangkan harga $\mathrm{X}$ yang kecil berpasangan dengan $\mathrm{Y}$ yang besar. Penelitian ini hargar bernilai negatif, dengan demikian jika siswa memiliki kecepatan, akan memberikan kontribusi terhadap dribble bola kaki dengan baik. Hal itu disebabkan semakin cepat seseorang akan semakin bagus pula dribble bola kaki sehingga waktu yang diperlukan untuk menempuh suatu jarak dalam dribble bola kaki akan semakin baik.

Sampel pada penelitian ini siswa putra Sekolah Menengah Pertama, saat penelitian terdapat beberapa siswa memiliki kecepatan namun dribble-nya masih kurang cepat, beberapa siswa mempunyai kecepatan namun kurang bersungguhsungguh saat melakukan dribble bola kaki. Faktor lain yang menyebabkan adalah kecepatan reaksi siswa pada saat start masih lemah, siswa sering terlambat berlari saat aba-aba yak selesai dan daya tahan an aerobik siswa masih rendah hal ini dapat dilihat setelah siswa melewati jarak lebih dari 40 meter kecepatan larinya berkurang.

Kecepatan merupakan salah satu komponen guna meningkatkan hasil dribble pada permainan bolakaki. Kecepatan lari ditentukan oleh dua aspek, yaitu panjang langkah dan frekuensi langkah. Tungkai pada tiap individu mempunyai ukuran yang berbeda sehingga berpengaruh terhadap perbedaan kecepatan lari tiap individu. Sehingga semakin panjang tungkainya akan dapat diikuti dengan jangkauan langkah yang semakin panjang sehingga waktu yang diperlukan untuk menempuh suatu jarak dalam lari akan semakin pendek, dengan kata lain waktu tempuhnya menjadi lebih cepat dan energi yang dikeluarkan akan semakin sedikit, hal ini tentu akan memberikan keuntungan bagi dribble. Hasil $\mathrm{r}_{\text {hitung }}$ 0,67 menunjukkan hubungan yang baik atau signifikan antara kecepatan dengan dribble.

Hubungan kelincahan dengan dribble bola kaki dapat diinterpretasikan dengan mengukur koefisien korelasi (r) nya. Besar koefisien korelasi antara kelincahan dengan dribble bola kaki adalah sebesar $r_{\text {hitung }} 0,63$, berarti 
sumbangan kelincahan terhadap drible pada permainan sepak bola sebesar $63 \%$ at, termasuk dalam kategori tingkat hubungan yang cukup tinggi. Berarti ada hubungan antara kelincahan dengan dribble pada siswa putra Sekolah Menengah Pertama meskipun kontribusinya tidak maksimal. Ini berarti bahwa titik-titik yang ditentukan oleh $(\mathrm{X}, \mathrm{Y})$ seluruhnya terletak pada garis regresi linier dan harga $\mathrm{X}$ yang besar menyebabkan atau berpasangan dengan $\mathrm{Y}$ yang kecil sedangkan harga $\mathrm{X}$ yang kecil berpasangan dengan $\mathrm{Y}$ yang besar.

Pada penelitian ini harga bernilai negatif, dengan demikian jika siswa memiliki kelincahan yang besar, maka waktu untuk menempuh dribble bola kaki akan kecil. Dengan kata lain kelincahan yang besar memberikan kontribusi terhadap kecepatan dribble bola kaki dengan baik. Sampel pada penelitian ini bukan siswa yang mengikuti ekstrakurikuler. Hal yang terjadi pada waktu penelitian beberapa beberapa siswa mempunyai kelincahan yang baik namun kurang bersungguh-sungguh saat dribble bola kaki, siswa memiliki kelincahan yang baik namun ketika mereka berlari hasilnya kurang memuaskan. Faktor yang menyebabkan hal itu terjadi dapat terjadi adalah daya tahan an-aerobik yang masih rendah.

Hasil penelitian ini menunjukkan bahwa kelincahan merupakan salah satu komponenpenting guna meningkatkan kecepatan dribble pada permainan bola kaki.. Menurut Sukirno (2012: 37), pelari sprint, selain diperlukan kecepatan tinggi juga diperlukan jarak langkah, dan power otot tungkai, frekuensi langkah, koordinasi teknik, kelentukan (flexsibility), dan daya tahan anaerobik, kesemuanya merupakan komponen yang harus dipenuhi oleh seorang pelari sprint, untuk menghasilkan kecepatan yang tinggi. Hasil $r_{\text {hitung }} 0,63$ menunjukkan hubungan yang cukup signifikan antara kelincahan dengaan dribble pada permainan bola kaki. Hal ini dapat terjadi karena kontribusi kelincahan besar dalam melakukan dribble bola kaki.

Hubungan kecepatan dan kelincahan dengan hasil dribble bola kaki dapat diinterpretasikan dengan mengukur koefisien korelasi (R) nya. Besar 
koefisien korelasi antara kecepatan dan kelincahan dengan hasil dribble bola kaki adalah sebesar $R_{\text {hitung }} 0,67$, termasuk dalam kategori tingkat hubungan yang cukup tinggi. Berarti ada kontribusi hubungan antara kecepatan dan kelincahan dengan dribble bola kaki pada siswa putra Sekolah Menengan Pertama, meskipun kontribusinya lemah. Harga " $r$ " bernilai positif, dengan demikian semakin cepat seseorang dan semakin besar kelincahan akan memberikan kontribusi dribble bola kaki.

Kecepatan merupakan komponen yang sangat penting bagi seorang pemain bola. Kecepatan lari ditentukan oleh dua aspek, yaitu panjang langkah dan frekuensi langkah. Tungkai pada tiap individu mempunyai ukuran yang berbeda sehingga berpengaruh terhadap perbedaan kecepatan lari tiap individu. Sehingga semakin panjang tungkainya akan dapat diikuti dengan jangkauan langkah yang semakin panjang sehingga waktu yang diperlukan untuk menempuh suatu jarak dalam lari akan semakin pendek, dengan kata lain waktu tempuhnya menjadi lebih cepat dan energi yang dikeluarkan akan semakin sedikit, hal ini tentu akan memberikan keuntungan bagi dribble. Menurut Widiastuti (2011: 110), daya ledak merupakan faktor utama dalam pelaksanaan segala macam keterampilan gerak berbagai cabang olahraga, karena daya ledak adalah kemampuan untuk mengerahkan kekuatan maksimal dalam waktu yang sangat cepat.

Menurut Sukirno (2012: 37), pelari sprint, selain diperlukan kecepatan tinggi juga diperlukan jarak langkah, kekuatan, power otot tungkai, frekuensi langkah, koordinasi teknik, kelentukan (flexsibility), dan daya tahan an-aerobik, kesemuanya merupakan komponen yang harus dipenuhi oleh seorang pelari sprint, untuk menghasilkan kecepatan yang tinggi. Dua variabel bebas pada penelitian ini secara bersama-sama masih lemah untuk menentukan hasil Dribble. Hasil $\mathrm{R}_{\text {hitung }}$ 0,67 menunjukkan hubungan yang cukup tinggi atau memiliki hubungan yang cukup signifikan kecepatan $\left(\mathrm{X}_{1}\right)$ dan kelincahan $\left(\mathrm{X}_{2}\right)$ dengan dribble (Y) pada permainan sepak bola. Hal ini dapat terjadi karena 
kecepatan dan kelincahan memberikan kontribusi yang besar dalam dribble bola kaki.

\section{KESIMPULAN}

Berdasarkan hasil analisis data dan pembahasan, maka dapat disimpulkan seagai berikut: (1) terdapat hubungan kecepatan $\left(\mathrm{X}_{1}\right)$ dengan kemampuan dribble bola (Y) diperoleh hasil sebesar $\mathrm{r}=0,67$ berarti kontribusi kecepatan sebesar 67\%, (2) hubungan kelincahan $\left(\mathrm{X}_{2}\right)$ dengan hasil dribble bola (Y) sebesar $\mathrm{r}=0,63$ maka kontribusi kelincahan $\left(\mathrm{X}_{2}\right)$ sebesar 63\%, dan (3) sedangkan hubungan kecepatan dan kelincahan secara bersama-sama dengan dribble bola (Y) sebesar $\mathrm{R}=0,67$ berarti kontribusi kedu variabel tersebut sebesar 67\%. Berdasarkan hasil tersebut di atas, maka disimpulkan kedua variabel $X_{1}$ dan $X_{2}$ secara bersama-sama memiliki hubungan yang cukup segnifikan dengan (Y), memiliki sumbangan sebesar 67\%, terhadap hasil drible pada permainan sepak bola walaupun tidak maksimal hubungan kedua variabel, berarti masih ada variabel lain yang mempengaruhi.

\section{DAFTAR PUSTAKA}

Arikunto, Suharsimi. 2010. Pengertian Hubungan. Jakarta: Bumi Timur Jaya.

Jones, Ken. 1988. Sepak Bola. Jakarta: Dian Rakyat.

Luxbacher, Joseph A. 2012. Sepakbola. Jakarta: Raja Gravindo.

Nala, I Gusti Ngurah. 2011. Prinsip Pelatihan Fisik Olahraga. Bali: Udayana University Press.

Sukirno. 2012. Kesehatan Olahraga, Doping dan Kesegaran Jasmani. Palembang: Unsri Press.

Sukirno \& Waluyo. 2016. Cabang Olahraga Bola Voli. Palembang: Unsri Press.

Sugiyono. 2008. Metode Penelitian Kualitatif dan $R$ n D. Bandung: Alfabeta. 

2011. Metode Penelitian Kualitatif dan R n D. Bandung: Alfabeta.

Suroto. 2004. Bahan Ajar Sepakbola. Jakarta: Departemen Pendidikan Nasional. Widiastuti. 2011. Tes dan Pengukuran Olahraga. Jakarta: PT Grafindo. 